\title{
Learning Chinese: Walter A. Taylor, an American Architect in China (1923-27)*
}

\author{
Stephanie Burette (iD) ${ }^{1}$ \\ Email: burette.stephanie@gmail.com
}

(Received 28 February 2021; accepted 31 March 2021; first published online 17 May 2021)

\begin{abstract}
The American architect Walter A. Taylor, who was an Episcopal missionary in China from 1923 to 1927, intended to 'desig[n] churches and other buildings that were Chinese and belonged to China'. ${ }^{2}$ Taylor found himself at a crossroads, between Christian architecture in his home country, the USA, which was experiencing a time of transition, and the birth of the Chinese Republic and its strong rejection of Western hegemony. This article investigates how Taylor tried to undertake his task, where he found inspiration and what this indigenized architecture looked like. I argue that, although his work aimed at participating in the shift towards indigenization, it bore the signs of Chinese culture as seen through the eyes of a Westerner and imperialism.
\end{abstract}

Keywords: China, Christian architecture, Gothic revival, indigenization, Walter A. Taylor

When the American architect Walter Andrews Taylor arrived in China in 1923 as an Episcopal missionary in order to design, mostly, schools and religious buildings, the architectural and political contexts were experiencing a profound transformation. In the West, the relevance of the new Gothic style for the church of the twentieth century - widely illustrated in the USA by Ralph Adams Cram (1863-1942) - was debated. ${ }^{3}$ While

${ }^{\star}$ I want to express my gratitude to Professor Chloë Starr, who introduced me to Chinese theology and thanks to whom I became interested in these papers in the first place. The librarians of Yale Divinity School have been, as always, outstanding and generous with their time and expertise. My deepest thanks to the anonymous readers at the Journal of Anglican Studies, for their very stimulating comments, thoughtful suggestions, and astute observations. I am deeply indebted to Professor Vasileios Marinis who so generously agreed to read countless drafts of this paper.

${ }^{1}$ Stephanie Burette is Chaplain and Solway Fellow at University College, University of Durham, UK.

${ }^{2 ‘}$ The Relation of Architecture to Worship', Church Management, XXXI.1 (October 1954), Walter and Ruth Marie Taylor Papers, 1923-1954, 2 linear feet (3 boxes) RG251:

http://drs.library.yale.edu/HLTransformer/HLTransServlet?stylename=yul.ead2002.xhtml.xsl\&pid= divinity:251\&clear-stylesheet-cache=yes, box 2, f. 24, pp. 1-3 (1).

${ }^{3}$ One can think of the 'Battle of Styles' which began in the nineteenth century, opposing supporters of the Gothic style to those of the Classical style, and Taylor himself fiercely opposed the new Gothic which resulted, in his view, from a backward-looking romanticism. See 'The Relation of Architecture to Worship', p. 2.

(C) The Author(s), 2021. Published by Cambridge University Press. This is an Open Access article, distributed under the terms of the Creative Commons Attribution licence (http://creativecommons.org/licenses/by/4.0/), which permits unrestricted re-use, distribution, and reproduction in any medium, provided the original work is properly cited. 
arguments over what constitutes appropriate religious architecture to build for the colonies of the British Empire had been going on in the Anglican church for almost two-thirds of a century, the relevance of the new Gothic 'overseas' had become questionable. ${ }^{4}$ The wish to adapt Christian architecture to the climates and cultures of non-Western parts of the world implied the necessity to study the techniques, materials (with the rationale behind their uses), and symbols favoured by indigenous architects.

Chinese architecture was no exception; it was still regarded as exotic and largely unknown to Westerners though a few, such as the German architect Ernst Boerschmann (1873-1949), were beginning to make it known in Europe. ${ }^{5}$ Meanwhile, for the Roman Catholic Church (whose presence in China, through Jesuit missionaries, dated back to the sixteenth century), two papal encyclical letters, Maximum Illud (1919) and Rerum Ecclesiae (1926), highlighted the importance of integrating the Christian faith with specific culture (what we would now call inculturation' or 'indigenization'). Along these lines, the Archbishop Celso Constantini, Apostolic Delegate to China from 1922 to 1933, strongly condemned Gothic and other Western styles, advocating instead for a Christian architecture rooted in Chinese art and culture. ${ }^{6}$

Furthermore, Taylor arrived at a turning point in Chinese history. The last imperial dynasty, Qing, established in 1636, had come to an end in 1912, and was being succeeded by the Republic of China. Meanwhile, the Boxer Rebellion (1899-1901) had made a strong anti-imperialist, anti-foreign and anti-Christian statement, ultimately resulting in putting a halt to Europeans' ambitions to colonize China. The following years were marked by two revolutions and the Chinese civil war, at the beginning of which (1927) Taylor and his wife were evacuated. ${ }^{7}$ That both the political climate and the architectural context were in transition is a major sign of a changing relationship to power within the country; Taylor found himself at the intersection of it all. Bearing this in mind helps us appreciate the complexity he had to navigate.

The Ruth Marie and Walter Taylor papers at Yale contain mostly personal letters, documents, articles, that Walter Taylor sent to his family and to his future wife, Ruth Marie, during his time in China between 1923 and 1927. ${ }^{8}$ While there, Taylor worked

\footnotetext{
${ }^{4}$ See G.A. Bremner, Imperial Gothic: Religious Architecture and High Anglican Culture in the British Empire, c. 1840-1870 (New Haven, CT: Yale University Press, 2013).

${ }^{5}$ After his travels to China between 1906 and 1909, Ernst Boerschmann organized an exhibition on Chinese Architecture at the Royal Museum of Decorative Arts in Berlin. It opened on 4 June 1912 and closed six weeks later on 20 July - 400 drawings and 152 photographs, all by Boerschmann, were on display. See Eduard Kögel, The Grand Documentation: Ernst Boerschmann and Chinese Religious Architecture (1906-1909) (Berlin: De Gruyter, 2015), p. 373.

${ }^{66}$ Western art in China is an error of style. It is an error to import European styles, Romanesque and Gothic, in China'. See 'L'universalité de l'art chrétien', Dossier de la commission synodale (special issue on Sino-Christian art), 5, pp. 410-17 (413), quoted by T. Coomans, 'A Pragmatic Approach to Church Construction in Northern China at the Time of Christian Inculturation: The Handbook "Le Missionnaire constructeur", 1926', Frontiers of Architectural Research 3 (2014), pp. 89-107 (103).

${ }^{7}$ Taylor's second son, Kenneth Warwick Taylor, reports in a one-page document entitled 'Ultimate Romance' about his parents: '[e]vacuation orders came and assisted by British and American gunboats down the river, on April 7, 1927 they left China'. RG251, box 2, f. 26.

${ }^{8}$ Personal letters include letters to his family members (his parents, Claud and Margaret, and his uncle Kenneth) and to Ruth Marie. They are mostly typed, sometimes handwritten, when he was travelling. Official writings include the articles he wrote for The Chinese Recorder (1924), The American Architect
} 
for the American Church Mission Architects based in Hankow, with John Van Wie Bergamini. ${ }^{9}$ He learnt Chinese and travelled around to study Chinese architecture and, in particular, the relationship between religious buildings and worship.

To be an American of English ancestry sent by the Episcopal Church to China was particularly charged in that period and Taylor was aware of it. ${ }^{10}$ The (occasionally self-reflective) writings of Walter Taylor demonstrate his sense of responsibility, particularly when China was going through turbulent times (1925-1927). ${ }^{11}$ As this study shows, Taylor's and his colleagues' ambition was to design buildings that would not replicate Western Christian architecture but would fit in with Chinese aesthetics and be appropriate for Chinese Christians' life and worship. This paper investigates how Taylor tried to rethink Christian architecture, by comparing his reflections and missionary work in China with his later writings in the United States, when he was an architect and instructor. I argue that his is a practical example of a Westerner who, participating in indigenization, reinforced the imperialistic attitude instead of transforming it. ${ }^{12}$ Taylor kept looking at the indigenous architecture through a Western lens, something that led him to make rather paradoxical decisions, even contradicting the rationale behind his strong criticism of the new Gothic architecture in the United States.

(1929), Church Management (1954), and reports on his activities in 1924 and 1926. Apart from the ones she sent to Walter, Ruth Marie's handwritten letters are addressed to her mother. Ruth Marie travelled to China in June 1926 and they married on 26 August 1926. The papers are in the Yale Divinity School archives on missionary work and the Christian Church in China.

${ }^{9}$ John Van Wie Bergamini (1888-1975), American missionary architect, worked for the American Episcopal mission in China and was appointed official architect of the Episcopal Church in the Far East in 1920. While in China, Taylor worked under Bergamini's supervision.

See RG251, box 3, pl. 1: 'The following buildings are selected from a list of over three hundred church, institutional and other projects which Mr. Taylor has served as architect, associated architect or consultant.' In China, Taylor worked with the 'American Mission Architects, Hankow, China, with J. V. W. Bergamini, A.I.A.', and the projects included: 'St. Paul's School Faculty Residence, Anking; St. John's Church additions, Hankow; Missionary Residences Hankow; St. Lois School Dormitory, Bishop's residence, Kaifeng; Central China Teacher's College, Attached Middle School, class and dormitory building, Wuchang; Central China University Faculty Residences [and] Dormitory, Wuchang; St. Andrew's Church, Parish hall and rectory, Wuchang; St. Joseph's school assembly and dining hall, Wuchang; Trinity Church rectory, Wuchang; Church General Hospital Additions, Wuchang, St. Paul's Church and Parish Hall, Yochow; Kuling American School, Kuling.' Date on the plate: 1 January 1940.

${ }^{10}$ 'There must be something in my English blood which makes me feel like a British colonial', letter of 13 June 1925 to his father, RG251, box 1, f. 5, pp. 1-2. See Figure 10.

${ }^{11}$ In a letter to his uncle Kenneth, dated 9 January 1927, Walter Taylor reports: 'Although the new Nationalist government seems to be functioning very efficiently and winning the support of the people by the most strenuous campaign of propaganda the world has ever seen, the left wing, the apparently uncontrolled element, of hangers-on, are violently Bolshevistic. So we are seeing repeated under our noses, the things that took place in Canton two or three years ago, with "Down with the British", "Down with Imperialism", "Destroy Capitalists and Imperialists", etc.', RG251, box 1, f. 6, p. 1.

About the Boxer Rebellion which preceded this period, see David A. Hollinger, Protestants Abroad: How Missionaries Tried to Change the World but Changed America (Princeton, NJ: Princeton University Press, 2017), p. 5, and Joseph W. Esherick, The Origins of the Boxer Uprising (Berkeley, CA: University of California Press, 1988).

${ }^{12}$ In that regard, Taylor is worth comparing with Herbert Baker in New Delhi and South Africa and Edwin Lutyens in New Delhi, two of his English contemporaries who sought to incorporate local and traditional features in a new, yet imperialistic, architectural style. 


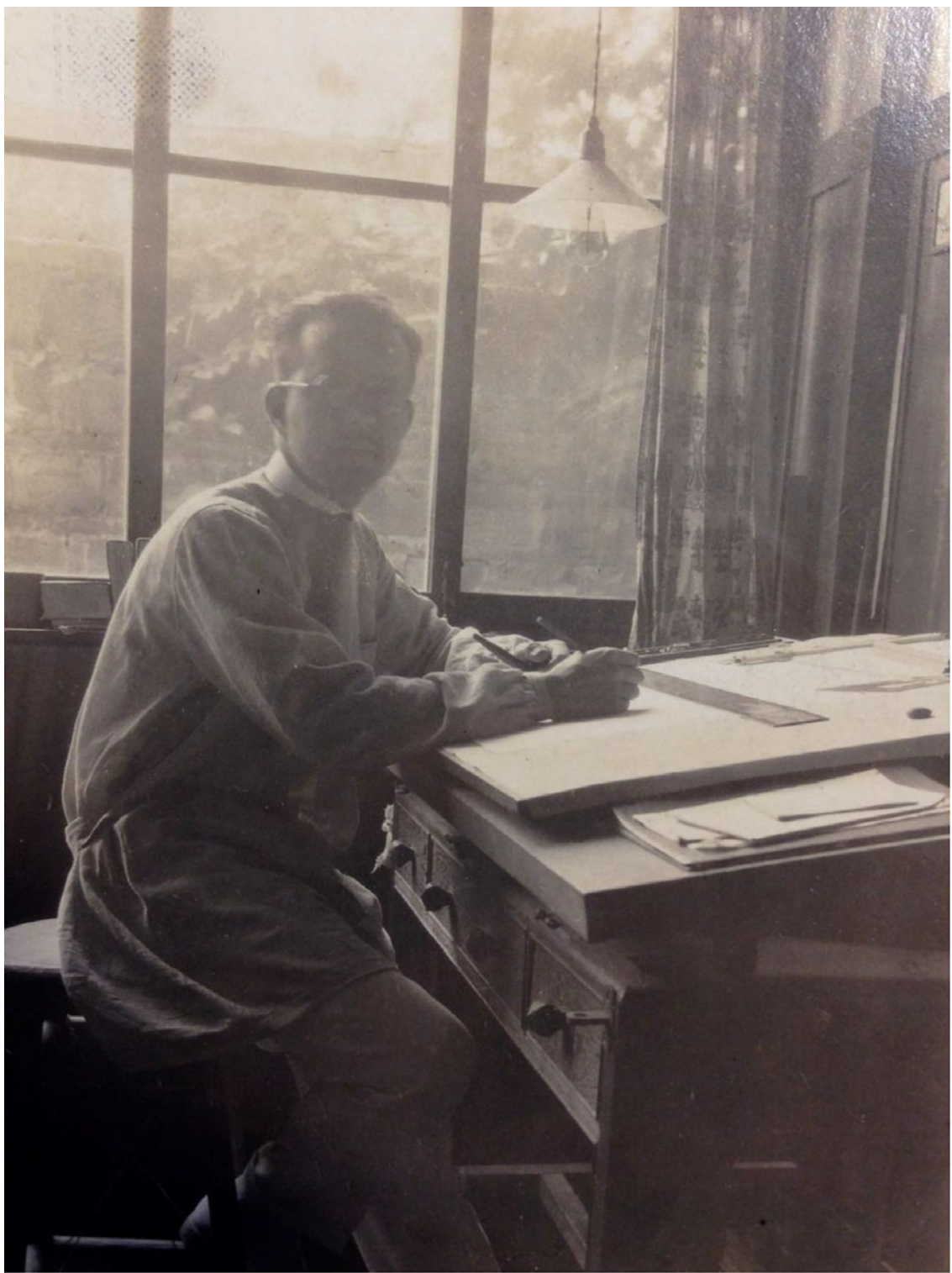

Figure 1. Walter A. Taylor, likely in his office at Boone University (undated). Source: RG251, box 2, f. 29, Special Collections, Yale Divinity School Library.

\section{Who? Where? Why?}

Walter Andrews Taylor was born on 16 February 1899 in North Canton, Ohio and died on 25 November 1963 (see Figure 1). He earned a Master's degree in Architecture from Ohio State University in 1921, studied (Chinese) language in Peking (1923-26), and became a Bachelor of Architecture at Columbia 
University in $1929 .{ }^{13}$ This American Episcopal architect was sent by the Episcopal Church to China, more precisely to Hankow, Hubei, in the Yangtze Valley, in 1923. ${ }^{14} \mathrm{He}$ was based at Boone University (as the heading of the paper he used for his correspondence indicates), named after the first Episcopal Bishop in China, Bishop William Jones Boone. ${ }^{15}$

Taylor worked as a missionary there between 1923 and 1927 (from the age of 24 to 28). ${ }^{16}$ In the first letter he wrote to his father, dated 28 May 1923, he explained that he had been sent to China because of a cut to the personnel of the acoustic department, where he was working:

It may be that they have been contemplating this and find in this China proposition a convenient occasion to dispense with me, although Mr Rankin said that that had no bearing. ${ }^{17}$

In a subsequent letter, to his mother, he writes: 'Apparently I am only the second architect to be sent to China by the Church. The other American engineers referred to by Mr. Bergamini were those with all the other missions. ${ }^{18}$ And a year and a half later, he tells her 'I am here for four years anyway', as he was encountering a period of doubt, not really knowing if all the work he was doing, especially at night because days were long and the warm and humid weather was particularly difficult for him - was of any worth. ${ }^{19}$

\footnotetext{
${ }^{13}$ The Harvard-Yenching Institute in Peking was established in 1928. Taylor may therefore have attended classes in what was a previous configuration of that Institute.

https://archives.yale.edu/repositories/4/resources/219?stylename=yul.ead2002.xhtml.xsl\&pid=divinity:

251\&clear-stylesheet-cache=yes

https://prabook.com/web/walter_andrews.taylor/1041629

${ }^{14}$ Hankow (or Hankou) merged later with two other towns and became Wuhan city, the capital of Hubei province.

${ }^{15}$ Boone University, Wuchang, Hupeh, China. This university became 'Huachung' University: 'Central China University'.

${ }^{16}$ Missionary' covers, for Taylor, two aspects of his work in China: both his paid work as an architect and his participation in the Church life, such as his appointment by the Bishop (Alfred A. Gilman) as member of the Council of Advice of the Episcopal Church in China (letter of 15 March 1925, RG 251, box 1, f. 5, p. 2), or as leader of a prayer group for the discussion of the first chapter of William Ralph Inge's book (Dean of St Paul's Cathedral, London) Personal Religion, on Christian mysticism and ritualism (letter of 7 June 1925, RG251, box 1, f. 5, p. 2).

Moreover, he also understood his letter writing as part of his missionary work: 'I do not mind admitting that this job [sending letters to his family] is more or less of a task, but I feel it is one of my most urgent duties, not only as a filial duty, but as a missionary[.] I feel very strongly that we should be missionaries in both directions, and whether you like it or not, I shall continue to spread propaganda and information as much as I can.' Letter of 15 March 1925, RG 251, box 1, f. 5, p. 1. On this duty as a missionary to make people 'back home' know more about the hosting country of the missionary, Hollinger explains how critical, yet imperfect, the sharing of their experience was: 'Missionary-connected Americans [ . . ] tried harder than did most of their contemporaries to take larger segments of humankind into account, intellectually, morally, and politically. They aspired to a world-wide human community that proved elusive. In their finest moments they grasped the profundity of the problem of solidarity.' Hollinger, Protestants Abroad, p. 299.

${ }^{17}$ RG251, box 1 , f. 2.

${ }^{18}$ Letter of 5 September 1923, RG251, box 1, f. 2.

${ }^{19}$ Letter of 14 April 1925, RG251, box 1, f. 5.
} 
At a time when he was more confident, reflecting back on his work, Taylor wrote in 1954: 'When I practiced in China for the Episcopal Church, I refused to do allegedly Gothic Churches. We designed churches and other buildings that were Chinese and belonged to China. ${ }^{20}$ At the time he wrote this, Taylor was back in the USA, encouraging people to imagine a religious architecture appropriate for his own time, instead of a 'regurgitated Gothic' which, on top of being a 'great financial extravagance,' demonstrated 'a high degree of absurdity resulting from backward looking romanticism'. ${ }^{21}$

In China, the context was different and yet his considerations were similar. In an article in The Chinese Recorder, published in October 1924, he wrote:

We cannot carry on in the foreign 'rut' and we cannot go over into the Chinese 'ditch'. We must travel the rough and uncertain but pleasant and interesting 'middle of the road'.2

In his words, Taylor aimed at 'combining foreign construction and facilities with Chinese in modern buildings in China' ${ }^{23}$ Aware of the several factors that shape any period or style of architecture (geographical, geological, climatic, religious, social, political and historical), he knew that China's architecture was shifting because of the particular context of the early twentieth century. He stated that he refused to export Western architecture, however 'splendid', to be set as an example to the Chinese, as he had witnessed it in foreign concessions and mission compounds. ${ }^{24}$ On the contrary, he thought that the duty of the missionary architect was to study the indigenous architecture (in terms of materials, techniques and symbols), and try and understand its meaning and purpose, and to explore new possibilities. To those who objected that Chinese architecture was pagan - and therefore unsuitable for religious (i.e., Christian) buildings - he replied that, apart from Gothic architecture, pagan Greek and Roman temples had largely influenced religious architecture in Europe and America. ${ }^{25}$ What he advocated for, instead, was a sort of translation of religious symbolism to make it understandable in the specific culture and context of China:

\footnotetext{
${ }^{20}$ Taylor, 'The Relation of Architecture to Worship', p. 2.

${ }^{21}$ Taylor, 'The Relation of Architecture to Worship', p. 2.

${ }^{22}$ The Chinese Recorder, October 1924, Walter A. Taylor, 'Chinese Architecture in Modern Buildings,' RG251, box 2, f. 24, p. 661.

${ }^{23}$ Taylor, 'Chinese Architecture in Modern Buildings', p. 657.

${ }^{24}$ Taylor, 'Chinese Architecture in Modern Buildings', p. 659.

${ }^{25} \mathrm{As}$ it is made even clearer years after his return to the USA, Taylor encouraged people to imagine a Christian architecture that could transcend time and space. Form and meaning were intertwined in his view but he regretted that his contemporaries had their minds fixed on Gothic architecture as the Christian style par excellence. In an article published in 1954, he wrote: 'We must recognize that a great deal of American church architecture of the past 150 years has not been a free, spontaneous expression of our culture. We are met to face this question: Can we permit the prostitution of architecture, a noble, creative art? Can we continue to countenance its use as a rubber-stamp trademark that says, "this is a church because it has pointed arches [?]." Those who say "this shall not be" must then answer the question, is there a Christian architectural leit-motiv which transcends time, geography and nationalism? The answer is "yes," and that really basic architectural tradition has been transposed and harmonized and expressed in a wide variety of architectural modes.' Taylor, 'The Relation of Architecture to Worship', p. 1.
} 
Missionaries try in many ways to adapt themselves to Chinese customs and put themselves to great trouble in order to be able to present their message in the Chinese language, yet many of them insist upon using architectural language which the Chinese cannot be expected to understand, and ignoring the possibilities of the beautiful and facile medium of expression close at hand. These same people fill their homes with all manner of things Chinese, and go into ecstasies over Chinese designs on vases, bronzes and tapestries, and yet ornament the outside of their buildings with poor copies of details ten generations removed from Europe, and 'milk bottle' columns which would make Vignola turn in his grave. ${ }^{26}$

In that sense, Taylor intended to participate in the process of inculturation, which he considered as a bilateral action: if missionary architects had to study Chinese architectural symbolism, it was not only because of the necessity to adapt the design of their buildings and ornaments to a particular culture and place, but also in order to understand its specific meaning. By doing so, they would open themselves to a new 'system of symbolism giving expression to fundamental ideas and spiritual conceptions' - which they had seen expressed by other systems of symbolism - that would influence in return the design of their future buildings. ${ }^{27}$

In all likelihood, Taylor found in his chief and supervisor, Bergamini, a likeminded collaborator. In the same issue of The Chinese Recorder, Bergamini wrote an article entitled 'Architectural Meditation' in which he introduced his views on his mission as an American architect in China: 'In building always keep the thought in mind: Is it appropriate? And when in China: IS IT APPROPRIATE FOR THE CHINESE SURROUNDINGS? We are guests in China. ${ }^{28}$ Going further on, he explained what he meant by 'guests':

People who at least should be considerate of the likes and dislikes of their hosts and yet we have built mission stations of grey brick, unpainted iron roofs and red woodwork some two or three stories high, sticking up like sore thumbs about the Chinese landscape[.] ${ }^{29}$

The carelessness Bergamini points out may remind us of Taylor's observations on the necessity of paying attention to the indigenous architecture. Yet, in the following comparison and comment, one wonders what Bergamini considered to be the role of missionary architects:

[D] ue consideration of the architecture of the surrounding building is necessary when determining the design of a new building. Good architecture, like a well dressed man, does not consist of loudness or freakishness but of a quiet harmony with its surroundings. The ideal mission building is one which is

\footnotetext{
${ }^{26}$ Taylor, 'Chinese Architecture in Modern Buildings', p. 660. Vignola (Giacomo Barozzi da): Italian architect (1507-1573).

${ }^{27}$ Taylor, 'Chinese Architecture in Modern Buildings', p. 658. In this process of creation, one might ask, though, where was the place of the indigenous people themselves.

${ }^{28}$ Bergamini, 'Architectural Meditations', The Chinese Recorder, pp. 650-58 (650).

${ }^{29}$ Bergamini, 'Architectural Meditations', p. 651.
} 
attractive, harmonizes with its surroundings and looks as little foreign as possible. The architecture of China is at the present day in a state of transition and time alone can show the ultimate outcome, but we can place good examples of what we consider appropriate architecture before the Chinese people. They are the ones who will decide and their taste is good. ${ }^{30}$

If the colonial attitude of Bergamini (to 'place good examples of what we consider appropriate architecture before the Chinese people') is obvious in this passage, the comparison with a 'well dressed man' may directly echo the attitude of the first Christian missionaries in China, such as the Italian Jesuit Matteo Ricci who wore the habit of a Buddhist monk to blend in with the crowd or, more accurately, be in 'quiet harmony with [his] surroundings' as Bergamini puts it, a Western chameleon trying to fit into the landscape. ${ }^{31}$ Therefore, what could be here described as the process of accommodation implies that the new architectural style would incorporate - and therefore would be transformed by - its surroundings. ${ }^{32}$ Again, the influence was meant to go both ways. Bergamini thus recommended that a missionary

\footnotetext{
${ }^{30}$ Bergamini, 'Architectural Meditations', p. 653.

${ }^{31}$ Matteo Ricci (1552-1610), an Italian Jesuit missionary who introduced Christian teaching to the Chinese Empire. A fellow Spanish Jesuit, Alonso Sanchez (1547-93), described Ricci as follows: 'Matteo Ricci, Italian, so similar in everything to the Chinese, and seems to be one of them in the beauty of his head and in the delicacy, gentleness and suaveness, which they value so highly, and especially in his great intelligence and memory. For besides being a very good theologian and astronomer, whom they [the Chinese] very much appreciate, he has learned in a very short time their language and many characters so that he could speak with the mandarins without an interpreter, a fact that they all admire and enormously enjoy.' R. Po-Hsia, A Jesuit in the Forbidden City: Matteo Ricci, 1552-1610 (Oxford: Oxford University Press, 2010), p. 70.

We can, however, at this point in the history of Christian mission in China, nuance this approach (by using Bergamini's remarks themselves). He certainly advocated for buildings that were 'Chinese', but one should not put aside the role of the Christian Chinese themselves. According to Bergamini, church architecture that looked indigenous was strongly favoured by Chinese Christians. In his article of 1924 in the Chinese Recorder, he writes: 'I do not know of a single case where the Chinese have not approved of the efforts made to use Chinese motifs and I have found them most appreciative of a westerner's clumsy efforts to "think" Chinese[.] In [one] case I submitted sketches for a church building to a native congregation, but later learned that the bishop did not approve of having a building which appeared like a Chinese temple, for a church. However, the Chinese persisted and the design was carried out.' Bergamini, 'Architectural Meditations', pp. 654-55.

In his article in the same issue of this journal, Taylor seconded that remark saying: 'It is sometimes maintained that the Chinese prefer foreign architecture. Chinese in contact with foreigners may express such a preference, with true Chinese diplomacy, and they may react unfavorably towards some of the attempts at Chinese architecture consisting merely of foreign buildings with Chinese roofs, but there has never been a representative and unbiased vote declaring a preference for foreign architecture'. Taylor, 'Chinese Architecture in Modern Buildings', p. 660.

${ }^{32}$ Commenting on the term 'accommodation', Chloë Starr writes: 'The process of Christianity emerging in Chinese thought and form in Ming and Qing China has traditionally been termed "accommodation", with reference to Matteo Ricci's methods of recasting Christianity in philosophical terms amenable to his Chinese audience and with a sympathetic interpretation of Chinese ritual. The term is used pejoratively by those who opposed his methods, but "accommodation" is not a bad term if it describes a two-way making room for, or adaptation of, religious casing. It implies generosity, and hospitality, on the part of both the one making room for the metaphysical newcomer and the one accommodating Christianity to a new sphere of religious experience. Later terms, such as "inculturation", "enculturation", and "contextualization", have been much debated in the models they propose for this overall process of religions being adapted to, emerging within, and acting as transformative agents in another culture.' Chloë Starr, Chinese Theology. Text and Context (New Haven, CT: Yale University Press, 2016), pp. 17-18.
} 
architect start with a study of Chinese temple architecture and symbols of Christian art in order to develop 'an architecture for the Christian church which is indigenous to the country'. ${ }^{33}$ That is precisely what Taylor intended to do.

\section{Studying Chinese and Chinese Architecture}

Taylor's intention to immerse himself in the Chinese culture began with his learning of Chinese along with visits to and studies of Chinese monuments and buildings.

Soon after his arrival in China, he wrote that he was about to go to Peking in order to attend a language school for about six months and learn Chinese. ${ }^{34}$ If learning Chinese was necessary for his work and interactions with Chinese colleagues and employees, exposure to and study of Chinese architecture were equally important and led Taylor to explore various places around the country. His particular interest was the history of the buildings, their characteristics insofar as they were related to practical aspects of the site and to weather, as well as the symbols and their meaning. In 1925 he wrote to his family:

I got eleven good pictures and some interesting sketches in Yochow, but I have by no means exhausted the archaeological possibilities of the place. It seems to have a much larger percentage of elaborate or monumental buildings, such as guild halls and temples, than does Wuchang. Wuchang has so often in the past been overrun by riots and rebellions that most of its buildings are comparatively new, and it also shows the effect of industrial development. ${ }^{35}$

If the willingness to study Chinese architecture in order to build appropriate buildings sounds very commendable, what is interesting and can be striking is how Taylor and his colleagues carried out their studies and what they deemed worth studying. $\mathrm{He}$ demonstrated a particular interest in 'archaeological possibilities' and turned away from the new buildings that resulted from industrial development. Though elaborate and monumental buildings would present finer examples and be thus more attractive to Taylor, especially for his religious architectural projects, this already shows some criteria which helped him filter the broad and varied Chinese architecture he was encountering.

What Taylor (and Bergamini too) understood by indigenous architecture mainly referred to the imperial period - before industrial development could be perceived in architecture - or what they could consider ancient enough to represent, through their Western lens, traditional (exotic) architecture. In search of the roots of what he would regard as authentic Chinese architecture, Taylor therefore had to move away from Wuchang (in Hubei province), something that is surprising for somebody who was so aware of the surroundings and landscapes in which he would erect new buildings.

\footnotetext{
${ }^{33}$ Bergamini, 'Architectural Meditations', p. 653.

${ }^{34}$ Peking is "the" city of China, especially architecturally, that is why Mr. Bergamini insisted that I go there rather than to the school at Nanking University.' Letter to his uncle Kenneth, 17 December 1923, RG251, box 1, f. 3, p. 1.

${ }^{35}$ Letter of 17 June 1925, RG 251, box 1, folder 5, letter 8, p. 5. Yochow, now called Yueyang, is a city in the Hunan province. Wuchang is a district in the city of Wuhan, capital of Hubei province.
} 


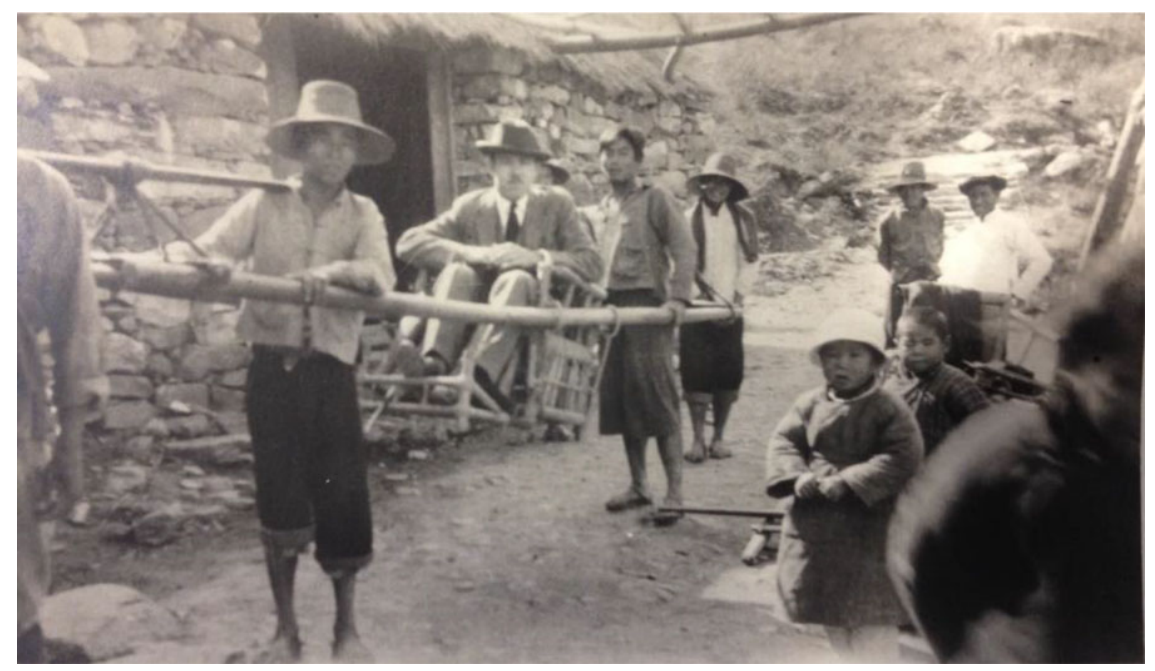

Figure 2. 'Walter and his chariot and four on the way down the mountain from Kuling' (Ruth Marie [Smith] Taylor's handwriting at the back, undated).

Source: RG251, box 2, f. 30, Special Collections, Yale Divinity School Library.

Taylor's archive preserves many photographs of the places he visited. Carefully organized and displayed on plates, they testify to his willingness to become familiar with style(s) he likely had no particular acquaintance with before arriving in China.

Moreover, he reported on his expeditions in several articles (see Figure 2). One that I have already mentioned was published in The Chinese Recorder, in October 1924. In that issue, Taylor was advocating for a 'middle of the road' between the foreign 'rut' and the Chinese 'ditch'. ${ }^{36}$ He therefore presented what he regarded as characteristic features of Chinese architecture, which he incorporated into the 'blended' architecture he was envisioning. One example of a characteristic feature is the 'wide projecting eaves of Chinese roofs, developed as a result of the intense sunlight and heavy rainfall'. ${ }^{37}$ This remark may seem minor, but it actually underlines how he saw the necessity of paying attention to the meaning behind certain shapes, which led to a proper imitation in further buildings made by Westerners. It was not only a matter of shape; there was a practical rationale behind it. Understanding it should prevent from overaccentuating the curve for example. By advocating for such considerations, Taylor was actually putting into practice what debates in the Anglican church of the nineteenth century had been putting forward for a 'successful transmission [of the Anglican church] abroad'. ${ }^{38}$

\footnotetext{
${ }^{36}$ Taylor 'Chinese Architecture in Modern Buildings', p. 661.

${ }^{37}$ Taylor 'Chinese Architecture in Modern Buildings', p. 657. In a later article, he recognized, however, that some could attribute meaning to this shape. They may be seen as 'spears and tent corners' and 'point out to ward evil spirits'. See 'An Architectural Pilgrimage in China', The American Architect, CXXXV.2570 (5 June 1929), RG251, box. 2, f. 24, p. 705.

${ }^{38}$ See Bremner, Imperial Gothic, p. 126: 'Although adaptation seemed commonsensical, it keyed with wider debates over "development" in Anglican church architecture during the mid-nineteenth century.
} 
In a later article, published in The American Architect in 1929, Taylor pushed his investigations much further and reported on '[a]n Architectural Pilgrimage in China', as its title put it. His pilgrimage was made to 'Tung Ling, or Eastern Tombs of the Manchu Emperors'. ${ }^{39}$ Illustrating his analysis with many photographs, Taylor put a particular emphasis on how carved ornaments, their decorative effect, along with symbols, symmetrical construction and Chinese characters (if any) related to the purpose of the building or monument. ${ }^{40}$ For example, he observed:

The major tomb groups are all similar in parts and plan arrangement. We may choose as a good and typical example Ching Ling, the Tomb of K'ang Hsi.

In accordance with the two inviolable canons of Chinese monumental architecture, the whole group is arranged almost exactly symmetrically about a north and south axis, around a series of courts, with the principal buildings facing south. Before the first gate are two symmetrically placed tablet halls almost exactly alike, each one flanked by elaborately carved or marble pillars of conventionalized clouds. ${ }^{41}$

In order to visit the Eastern Tombs of the Qing dynasty, Taylor had to travel more than 800 miles north from Hankow (Wuhan), which was a lengthy journey (mostly by train) at that time. Furthermore, it is interesting that he chose to get inspiration from royal tombs for the religious architecture he wanted to create. More specifically, though the Qing dynasty lasted until 1912, the monuments he reported on (related to emperor K'ang Hsi) dated back to the seventeenth and eighteenth centuries. ${ }^{42}$ Instead of choosing more modern buildings and having the new ones be in line with them, Taylor considered a previous stage of architectural development.

To talk about 'two inviolable canons of Chinese monumental architecture' potentially conveyed to the Western reader, who was very unfamiliar with Chinese architecture, the impression that it was monolithic. Though the continuity in it is quite

The Camden Society was itself undergoing a reformation at this time as it began lifting its horizons in a bid to reinvigorate its own agenda and head off accusations of "copyism". [Benjamin] Webb had also pointed out that although an Englishman abroad might well prefer the architecture of his own country, and that "English Pointed" was certainly recognised as having a peculiar excellence, it could not be condoned as "the model for every church in any climate." To be sure, the "essentials" of the Middle-Pointed style ought to remain as the basis of proper ecclesiastical architecture, but appropriate modification was now vital to its successful transmission abroad.' In 1845, Benjamin Webb, one of the founders of the Cambridge Camden Society, published 'On the Adaptation of Pointed Architecture to Tropical Climates', Transactions of the Cambridge Camden Society.

${ }^{39}$ Taylor, The American Architect, p. 705. The Manchu Emperors refers to the Qing dynasty (1636-1912).

${ }^{40}$ Some (unfortunately not all) original photographs are kept in box 3 of the Taylors papers, although all pictures in the article are credited to Walter A. Taylor.

${ }^{41}$ Taylor, The American Architect, p. 703. K'ang Hsi (or Kangxi) was the fourth emperor of the Qing dynasty (1661-1722), born and died in Beijing (1654-1722).

${ }^{42}$ In Chinese Architecture, Cai Yanxin notes that the Western Tombs (built between 1730 and 1915) 'were the last mausoleum complex ever built in the Qing Dynasty and the last site of tombs of feudal emperors in China, and are the fullest expression of ancient Chinese architectural form, design and technology. The range and quantity of architectural evidence and historical documents relating to the Western Tombs helps $[s i c]$ to illustrate the significant change in the religious beliefs of the imperial family between the $1730 \mathrm{~s}$ and the early twentieth century.' Cai Yanxin, Chinese Architecture (Cambridge: Cambridge University Press, 2011), pp. 60-61. By choosing the Eastern Tombs, Taylor therefore did not integrate the 'new' buildings in this evolution that he could have observed there. 
remarkable, Chinese architecture as rendered by Taylor's reports may have seemed a more harmonized picture than it really was. ${ }^{43} \mathrm{He}$ created this sense of harmony and continuity through what he selected, which rather (and interestingly enough) corresponded to the period Europeans had become aware of Chinese art, and which led to the chinoiserie trend and Orientalism current in the seventeenth and eighteenth centuries.

Moving to the tomb group of K'ang Hsi's grandson, Chien Lung, Taylor noticed the following distinctive attributes, which, for him, summed up 'all the characteristics' he was looking for:

Here are exhibited all the characteristics and details of Chinese monumental architecture. Uniformity, the outstanding characteristic, is to be observed in every part. There are the dragon-embossed ends of the tiles, so formal in contrast to the haphazard abruptness of Spanish and Italian tiles. The bronze animals and incense urns, the blue and white eyes on the closely spaced show rafters, and the procession of little beasts riding the hips of the roofs vary but little from the same details of many other buildings. ${ }^{44}$

After describing some other tombs and monuments, including the Spirit Hall, and their architectural characteristics, Taylor conveniently ended his article with illustrations of St Andrew's Church (Wu Chang, China) attributed to Bergamini, with this caption: 'Modern adaptation of Chinese Temple Architecture for a Christian Church Edifice' (see Figures 3-6).

That Taylor took so much notice of the ornamentation was another trait he shared with Anglicans in the nineteenth century. As the prominent Victorian art critic John Ruskin (1819-1900) put it in The Stones of Venice: '[ . . ] all noble ornament $[\ldots]$ is the expression of man's delight in God's work. ${ }^{35}$ Ruskin's interpretation of nature presenting underlying moral lessons 'transformed the meaning and intent of ornamentation in ecclesiastical architecture'. ${ }^{46}$ A church building could thus be regarded as a 'sermon in stone', and the concern for symbolism in church architecture 'was explicitly associated with identity in the High Anglican mind'. ${ }^{7}$ The task of both clergy and architects was thus to adapt Christian symbols to the particular contexts they were transferred to or 'accommodated'. ${ }^{48}$

\footnotetext{
${ }^{43}$ In Chinese Architecture, Laurence G. Liu states: 'The unique culture and geographic environment of ancient China had worked together to produce an architecture which not only differed from the architecture of the rest of the world, but which also had retained its continuity for almost 2,000 years. [T] hat there was [sic] only minor changes made throughout such a long period is not only unusual within such a large nation, but is also a remarkable achievement worldwide.' Laurence G. Liu, Chinese Architecture (London: Academy Editions, 1989), p. 27.

${ }^{44}$ Taylor, The American Architect, p. 704. Chien Lung (or Qianlong) was the sixth emperor of the Qing dynasty (1735-1796), born and died in Beijing (1711-1799).

${ }^{45}$ Quoted by Bremner, Imperial Gothic, p. 193.

${ }^{46}$ Bremner, Imperial Gothic, p. 193.

${ }^{47}$ Bremner, Imperial Gothic, p. 200.

${ }^{48}$ Bremner gives the example of All Saints' Cathedral in Allahabad (India), where a gargoyle was shaped in the form of a tiger emerging from the jungle, another gargoyle was in the form of a crocodile, with lotus leaves and blossoms (1870-1887). As it had been true in medieval Christian art, the fauna and flora could help reflecting in the building the particular context in which it was erected. Bremner, Imperial Gothic, p. 198.
} 


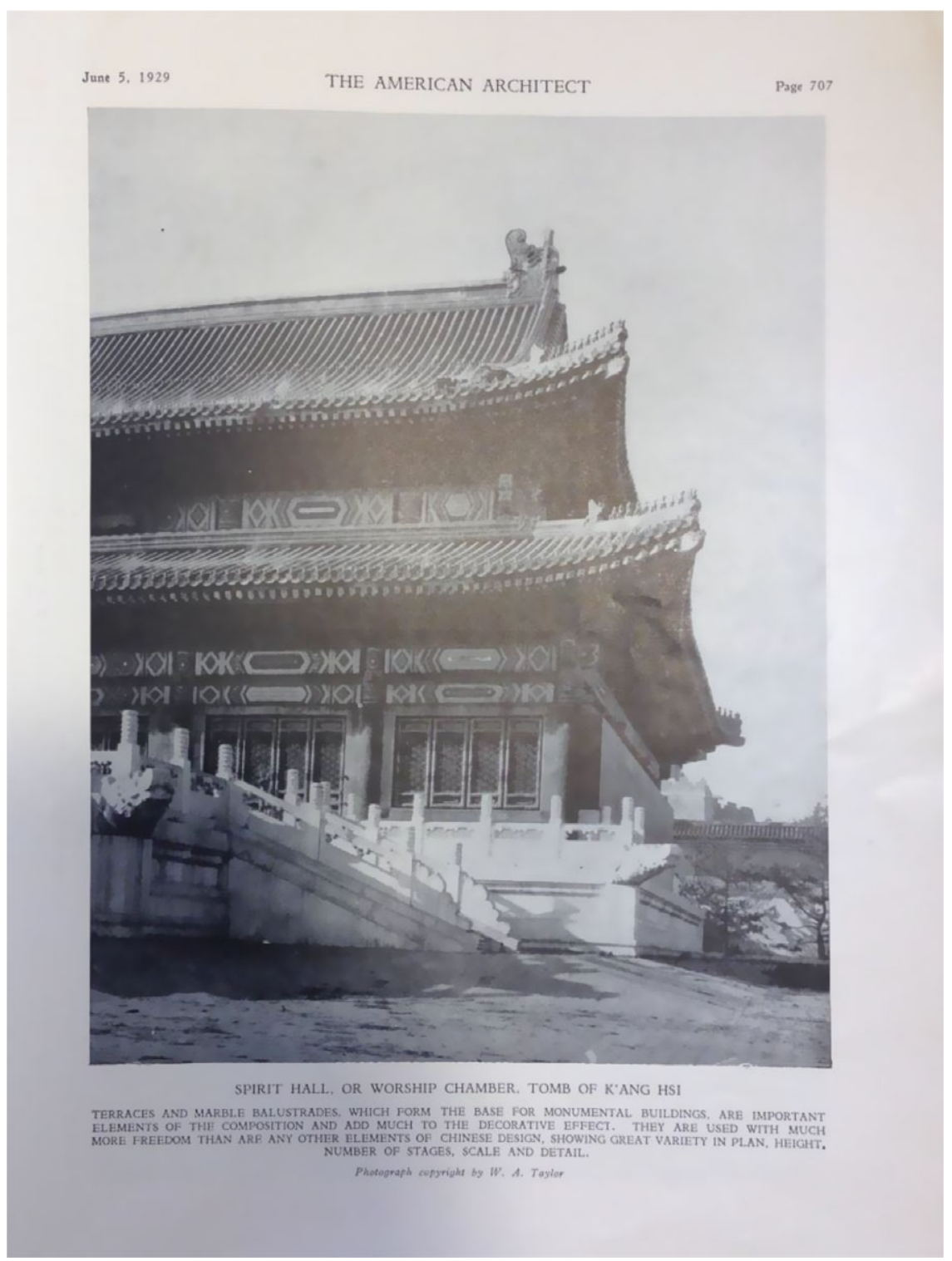

Figure 3. The American Architect, 5 June 1929.

Note: The caption says: 'Spirit Hall, or Worship Chamber, Tomb of K'ang Hsi. Terraces and marble balustrades, which form the base for monumental buildings, are important elements of the composition and add much to the decorative effect. They are used with much more freedom than are any other elements of Chinese design, showing great variety in plan, height, number of stages, scale and detail.'

Source: RG251, box. 2, f. 24, p. 707, Special Collections, Yale Divinity School Library. 


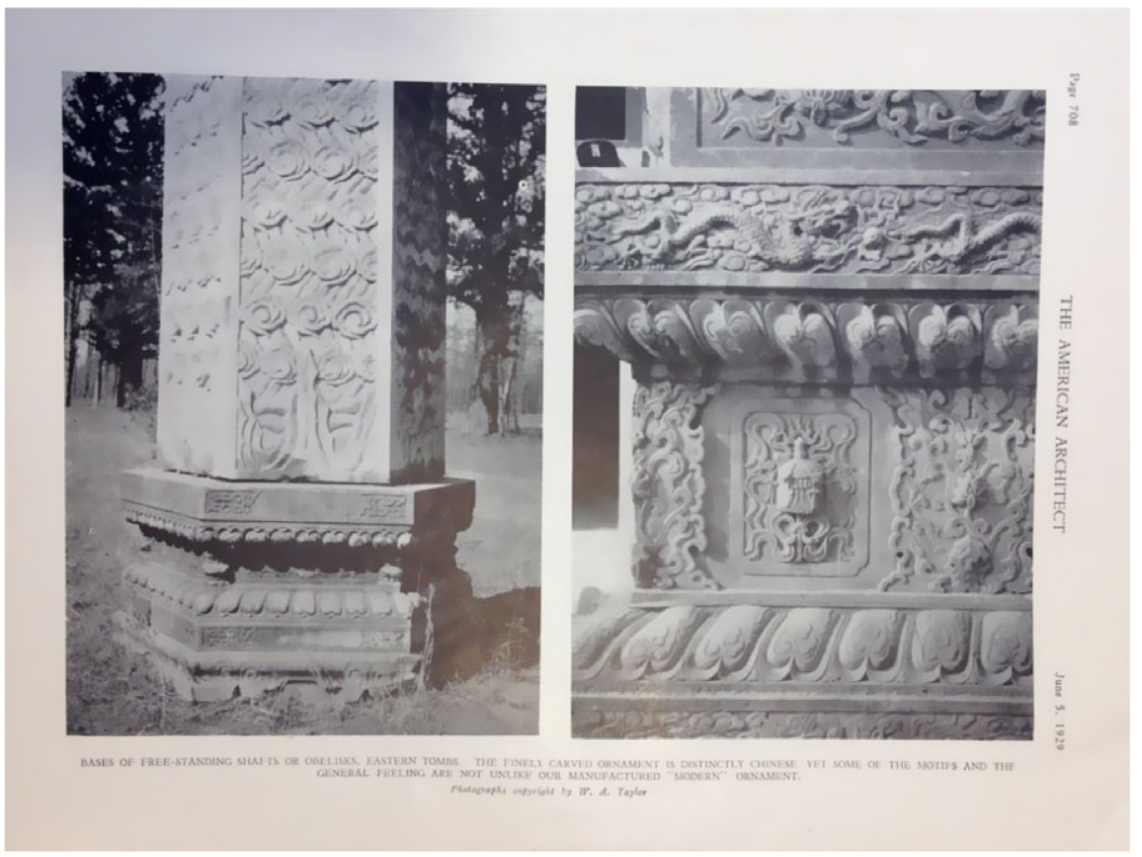

Figure 4. The American Architect, 5 June 1929.

Note: The caption says: 'Bases of free-standing shafts or obelisks, Eastern tombs. The finely carved ornament is distinctly Chinese. Yet, some of the motifs and the general feeling are not unlike our manufactured "modern" ornament'. Source: RG251, box. 2, f. 24, p. 708, Special Collections, Yale Divinity School Library.

The symbols Taylor could find among the Eastern Qing Tombs were connected to the Emperors' power. If he and Bergamini included some in the buildings they created, none of the photographs in his personal papers or articles testifies to it. However, if we look more closely at the photographs he took of his work, we can notice how he mostly imitated designs and what Christian symbols he incorporated. The following two pictures are close-ups from St Andrew's Church pictured above:

In Figure 7, one can recognize on the moulded baluster the Greek letter Chi, the

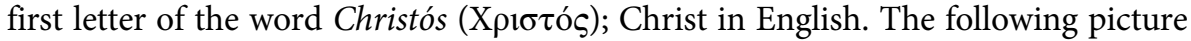
(Figure 8) shows the other symbol on the opposite baluster: a lamb with vexillum, or banner. Christ is described as 'the Lamb of God' in Jn 1.24 and the vexillum is a sign of the resurrection, a statement that, through his death and resurrection, Christ has taken away the sins of the world. The two symbols, almost side by side, respond to each other. Finally, on the third picture (Figure 9), one can notice in the background a cross enclosed in a circle. It contains a circle itself, and its four branches end with a square, which echoes another one at its centre. The poor quality of the photograph makes the identification of the design rather difficult, though it seems to replicate some of the designs photographed by Taylor. Based on these few elements, it looks like for Taylor (and Bergamini) the new and 'blended' architecture was the result of combining Chinese designs with fairly conventional Christian symbols (dating back to the Roman Empire). 


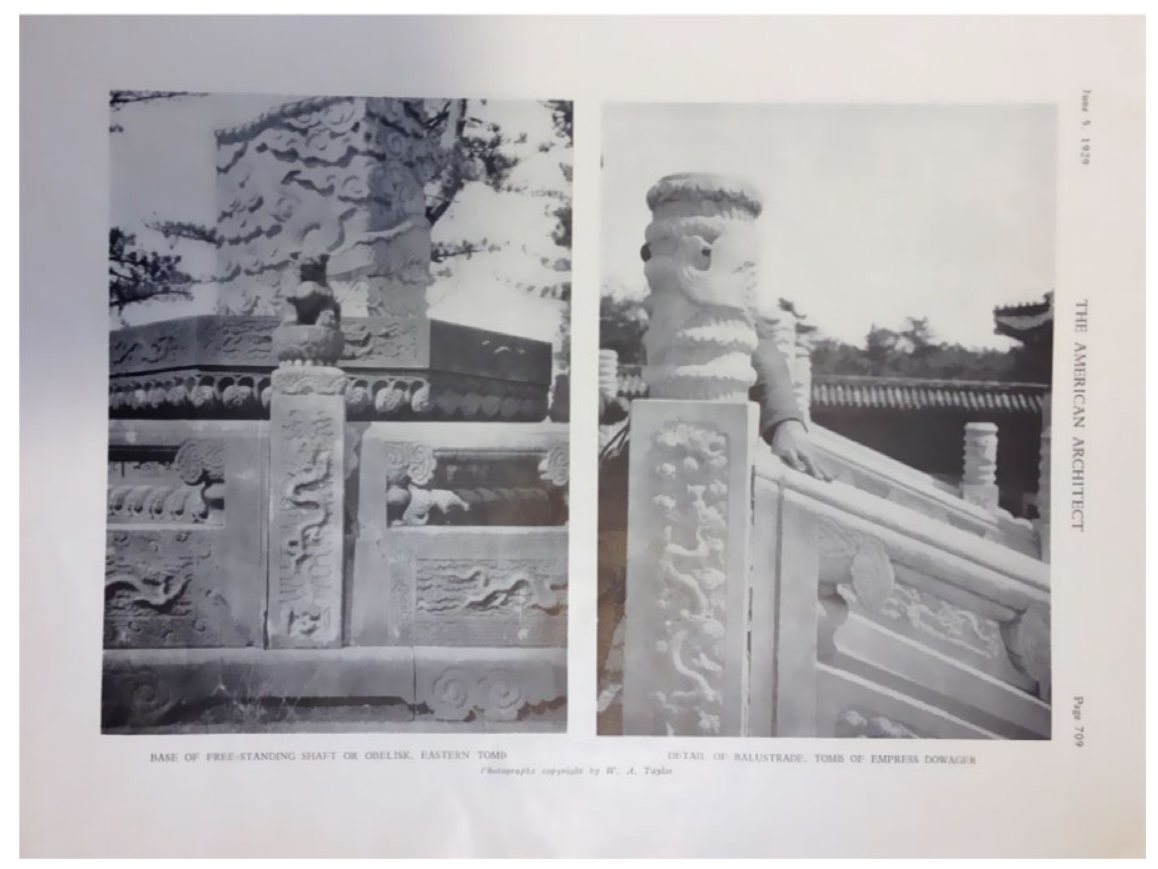

Figure 5. The American Architect, 5 June 1929.

Note: Caption says: (left) 'Base of free-standing shaft or obelisk, Eastern tomb'. (Right) 'Detail of balustrade. Tomb of Empress Dowager.' [Empress Dowager Cixi (1861-1908)]

Source: RG251, box. 2, f. 24, p. 709, Special Collections, Yale Divinity School Library.

If his purpose was to teach his readers what he identified as some characteristic features of Chinese architecture, Taylor was also aiming at demonstrating how Bergamini managed to create a modern building inspired by what he considered to be indigenous architecture. ${ }^{49}$ By paying significant attention to the inherited culture, Taylor believed that missionary architects could create buildings that would honour the Chinese tradition, while attending to the needs of their particular time and context. Furthermore, as he had noted in The Chinese Recorder: 'the foreign architect who is really a designer can design in the Chinese style if [...] he will use judiciously the taste and talents of native artisans. ${ }^{50}$ Taylor did not comment very often in his letters on his work with local artisans and one can wonder what he meant by 'judiciously'. As we have seen, Taylor targeted a particular period for his selection of Chinese architectural features and it would certainly have made sense to him to select also native artisans that would help him replicate this particular style. In a letter to his family he reported on how he participated in the realization of the ornaments for St Andrew's Church built by Bergamini:

We ran out of funds on St. Andrew's Church, but before the good mason contractor returned to Tientsin, I got most of his work out of him, work

\footnotetext{
${ }^{49}$ Bergamini, 'Architectural Meditations', p. 653.

${ }^{50}$ Taylor, The Chinese Recorder, p. 660.
} 


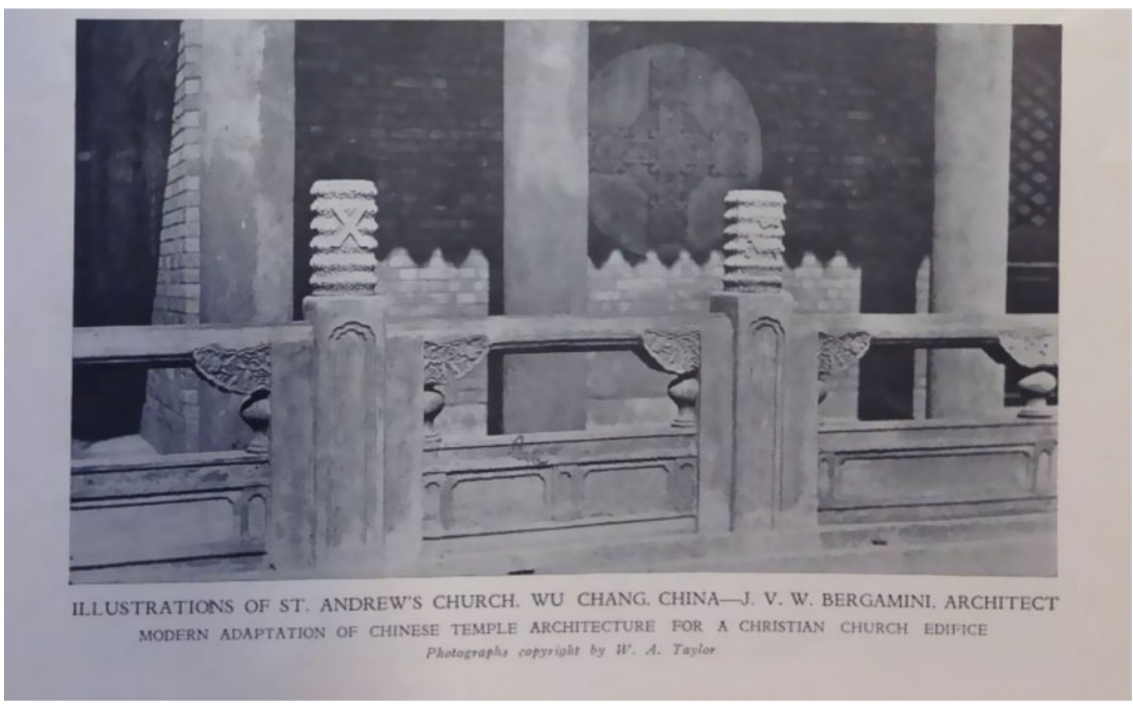

Figure 6. The American Architect, 5 June 1929.

Note: Caption says: 'Illustrations of St. Andrew's Church Wu Chang, China - J.V.W. Bergamini, architect. Modern adaptation of Chinese temple architecture for a Christian church edifice'.

Source: RG251, box. 2, f. 24, p. 710, Special Collections, Yale Divinity School Library.

which could not be done by the stupid Huhpeh masons. I enjoyed very much doing some nice things in molded concrete, adaptations of Chinese ornaments to Christian symbolism, which everyone seems to like. My only concern is whether or not Bergamini will like what I have done to his biggest and finest job. I do not like to have to do so much on what another man considers his masterpiece, but still I am glad to be able to claim some of the credit which we think will be due. ${ }^{51}$

We cannot be sure (although we might guess) that the picture he inserted in his article in The American Architect was showing part of his work for St Andrew's Church. Nevertheless, the article was clearly illustrating how he understood his mission and what he identified as a good 'adaptation of Chinese ornaments to Christian symbolism'. ${ }^{52}$ And in this letter, we hear of his credit to a good mason contractor, whom he had selected because of his ability. Whether he received feedback on the ornaments he designed, from this local mason or Chinese people (who is 'everyone'? Who are these people who seemed to like his adaptations?), we unfortunately do not

\footnotetext{
${ }^{51}$ Letter of 4 October 1925, RG251, box 1, f. 5, p. 2.

${ }^{52}$ In a letter to Ruth Marie, he explained that Bergamini was on furlough (in 1926) and that Taylor therefore found himself in charge of the office, which may be why he had to design ornaments on Bergamini's behalf: 'I am The Architect this year, as my chief is taking a years [sic] furlough, and I have 50,000 dollars worth of buildings (which means a lot in this country) to be designed and built. It would take a long list to enumerate all the miscellaneous jobs besides the various church and school and dormitory and residence buildings, and swimming pools and wells and ater-towers $[s i c]$ and numerous alterations, all of which keep me out of mischief and too busy to be homesick.' Letter of 8 July 1926, RG251, box 1, f. 10, p. 2.
} 


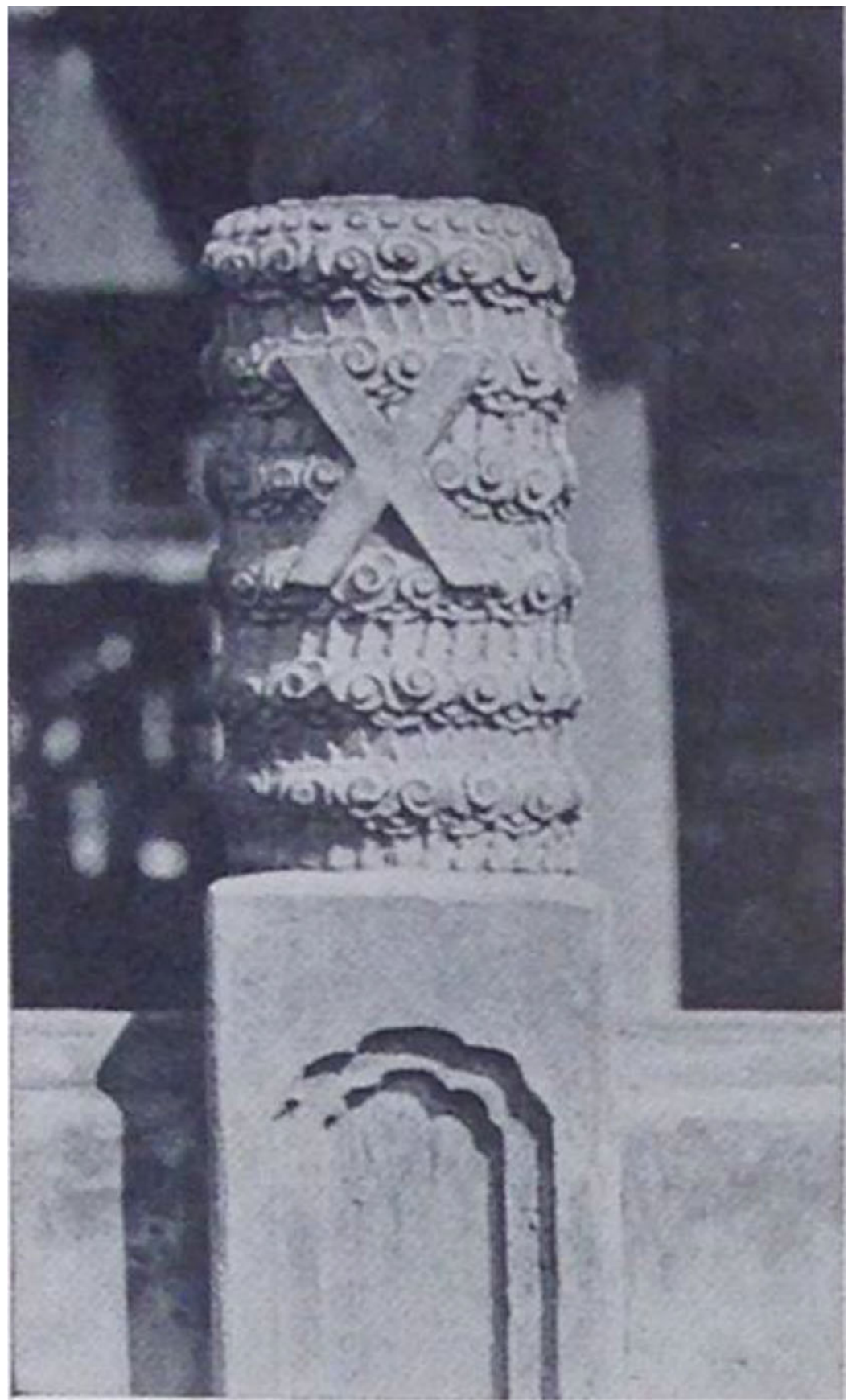

Figure 7. The American Architect, 5 June 1929.

Source: RG251, box. 2, f. 24, p. 710, detail, Special Collections, Yale Divinity School Library. 


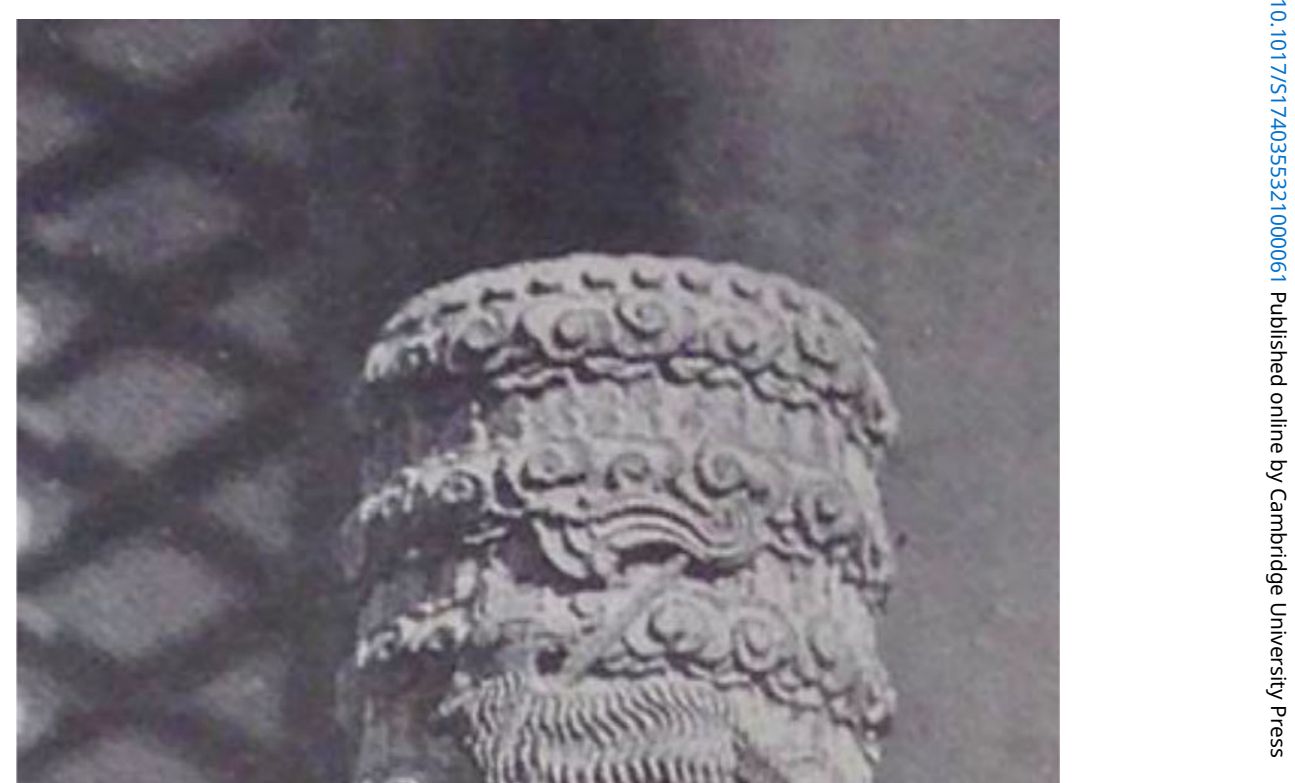

Figure 8. The American Architect, 5 June 1929.

Source: RG251, box. 2, f. 24, p. 710, detail, Special Collections, Yale Divinity School Library. 


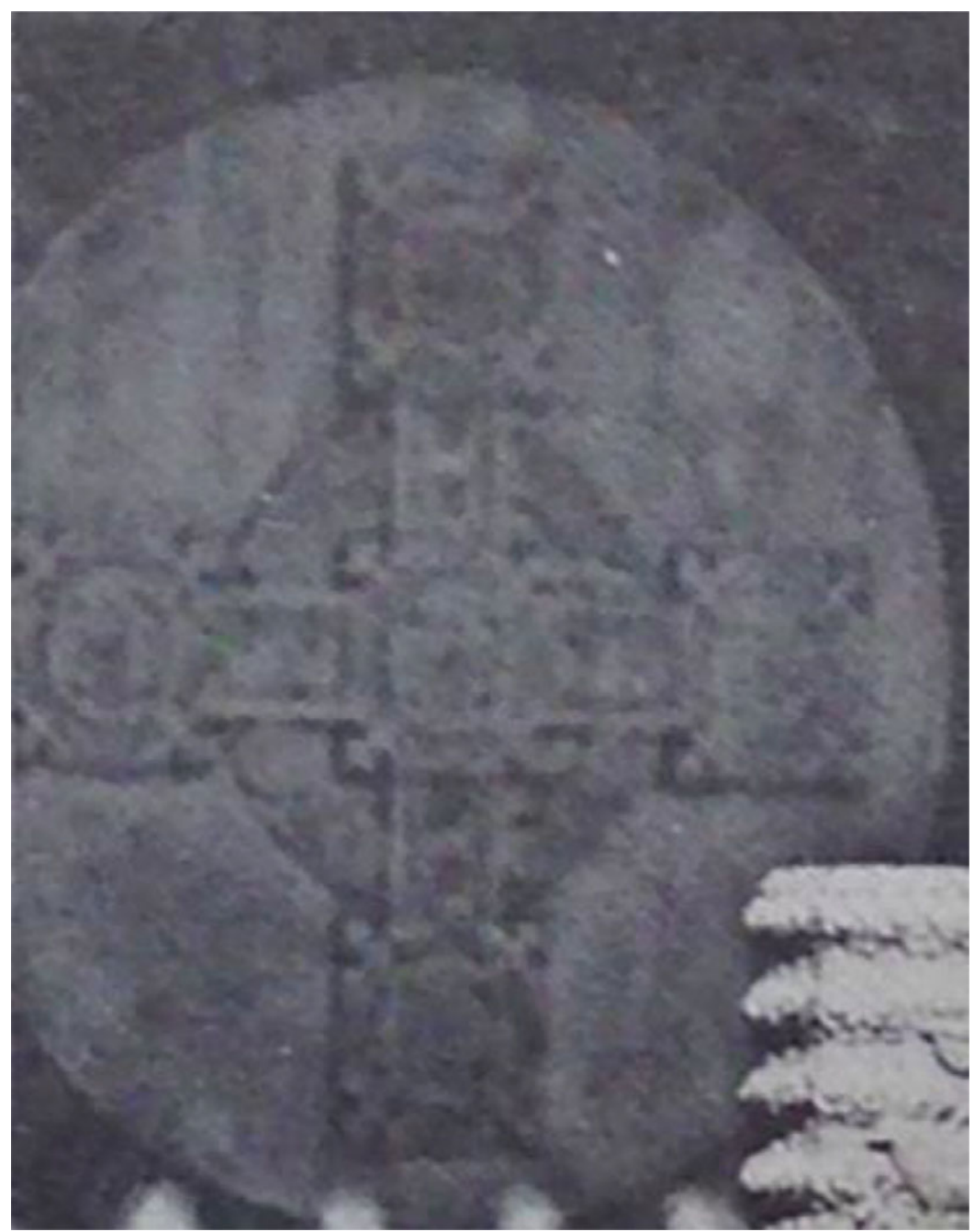

Figure 9. The American Architect, 5 June 1929.

Source: RG251, box. 2, f. 24, p. 710 (detail in the background), Special Collections, Yale Divinity School Library.

know. However, we can venture to hypothesize that the way the Chinese perceived his own work did matter to him. One sign of this is how bothered he was by the attitude of some missionaries, or foreigners in general, whose lack of curiosity and interest in Chinese culture and people were blatant. In a letter to his family, he wrote about foreigners in Hankow:

It is really a crime to send people to China with the mental and spiritual equipment that some of these folks have. Of course missionaries are queer and biased, but they will never be able to understand the man who spends most of a life time in a treaty port in China and boasts that he does not know more 


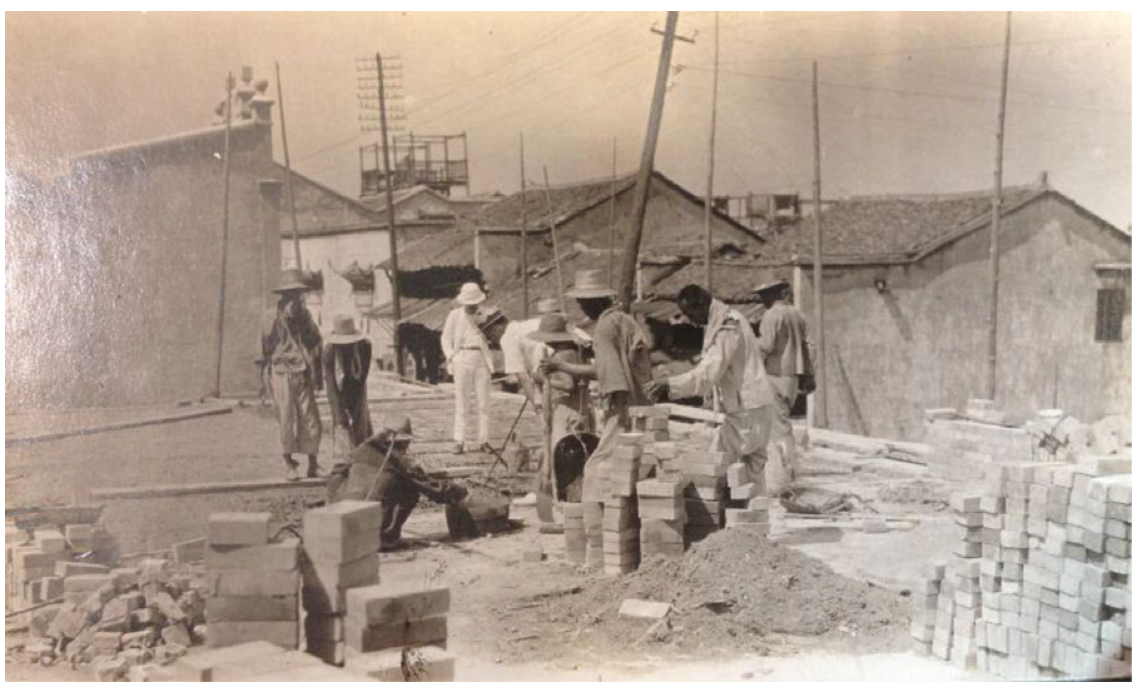

Figure 10. Walter A. Taylor on the construction site of St. Andrew's Church, Wuchang, China. Source: RG251, box 3, Special Collections, Yale Divinity School Library.

than six words of Chinese, and does not know any Chinese people personally or socially, and who would not go beyond the limits of the concession except for urgent business reasons. Many of the women of the American Women's Club are terrified at the idea of crossing the river to meet with Mrs. Miller or Mrs. Bliss, and think it is a great adventure when they come once or twice a year. ${ }^{53}$

Taylor admitted that he adopted a colonial attitude, which is also quite obvious in the pictures that show him supervising workers on construction sites with the distinctive British colonial outfit (white pith helmet, pale linen suit and trousers, smoking pipe). In the midst of riots in Hankow, he shared with his father his reflection on being a white man:

Bishop White has called off my side trip to Kaifeng, Honan. I don't mind admitting that we were all pretty scared when we first heard about this affair yesterday, and I thought of how nice and peaceful it must be at home, etc., but still I do not have any feeling of being a pale martyr missionary. There must be something in my English blood which makes me feel like a British colonial, with this instinctive 'white man' complex which says that this is all part of the job of being a white man, and that Englishmen have been doing this sort of thing for years and years, and that I am not living up to the race if I allow myself to get panicky about a few hundred heathen coolies.

\footnotetext{
${ }^{53}$ Letter of 7 June 1925, RG251, box 1, f. 5, p. 2.
} 
This idea of the superiority of the white man is very undesirable according to some people, but it is really largely racial antipathy, The Chinese have it just as much or more. The average Chinese would object just as strongly to his sister's marrying a white man, as I would to the converse. ${ }^{54}$

The undisguised sense of superiority and racism expressed by Taylor in this passage strongly highlights how distant he felt from the Chinese people, which contrasts with the curiosity he expressed towards an architectural style with which he was not familiar but which he respected and was eager to understand ${ }^{55}$ And this disconnection may have been problematic for what he wanted to create: churches fully integrated in the culture and life of Chinese people. The riots increased and, along with financial difficulties, they put his projects to an end. ${ }^{56} \mathrm{He}$ was evacuated and went back to the USA in $1927 .{ }^{57}$

In the span of four years, Taylor contributed to thirteen buildings (including churches, dormitories, schools, and residences, etc.) in China and one in Japan, with The American Church Mission Architects, as he was based in Hankow, with Bergamini as his chief. He served there as an architect, associated architect and consultant. The buildings were situated mostly in Hankow, but also in Anking, Kaifeng, Wuchang, Yochow, Kuling, and Tokyo. ${ }^{58}$

\section{Later Reflections on Architecture and Worship}

Walter Taylor's work in architecture and for the Church did not stop, however. Back in the USA, he lectured at Columbia University. He then became a professor in the Department of Architecture at Syracuse University, from 1936 to 1946, and Director of the Department of Education and Research at the American Institute of Architects (1946-1959). At the end of his career, he was Dean of the School of Architecture at Ohio University, from 1959 until 1963, when he died. ${ }^{59}$ Meanwhile, he also continued to give addresses and write articles. Two of his published addresses have been kept among the papers. The first was delivered "before the joint meeting of the department of Church building and Architecture of the National Council of Churches and the Church Architectural Guild', meeting in Knoxville, Tennessee, on 5 January 1954, while Taylor was working at the Institute of Architects and was Chairman of the Commission on Architecture of the Department of Worship and Arts of the National Council of Churches. ${ }^{60}$ The second was delivered 'at the annual meeting of

\footnotetext{
${ }^{54}$ Letter of 13 June 1925, RG251, box 1, f. 5, pp. 1-2.

${ }^{55}$ See n. 10 above, and Figure 10.

${ }^{56} \mathrm{He}$ wrote to his uncle Kenneth in a letter of 9 January 1927: 'we are seeing repeated under our noses, the things that took place in Canton two or three years ago, with "Down with the British", "Down with Imperialism", "Destroy Capitalists and Imperialists", etc. [... ] For the moment there is much uncertainty about building program, as about many matters of mission policy. Many of our jobs have been put on the shelf, and there is certainly no rush around our office.' RG251, box 1, f. 6, p. 1-2.

${ }^{57}$ His son Kenneth Warwick Taylor wrote about it, see n. 7 above, RG251, box 2, f. 26.

${ }^{58}$ See n. 9 above.

${ }^{59} \mathrm{https} / / /$ archives.yale.edu/repositories/4/resources/219? stylename=yul.ead2002.xhtml.xsl\&pid=divinity: 251\&clear-stylesheet-cache $=$ yes

${ }^{60}$ Taylor, 'The Relation of Architecture to the Worship', p. 2.
} 
the Church Architectural Guild of America at Atlanta, Georgia in March, 1956' while Taylor was occupying the same functions. ${ }^{61}$

In the first address, he invited both clergy and lay people to think about a Church architecture appropriate for the twentieth century in the USA. Although there are perennial needs of Christian communities that affect Church architecture, he also underlined that there are particular ones related to specific times. What was he witnessing around him?

I believe that it is generally recognized that we are at a period of crisis in the moral and ethical life of the nation in terms of our relationships to each other and to the rest of the world. There is something like a mass turning to religion. The percentage of church membership is increasing at double the rate of increase of the population. [...] This new, surging impulse as it moves into the organized churches or results in the formation of new congregations may require new types of programs, methods and facilities. ${ }^{62}$

What role could architecture play in that period of crisis? Quoting Von Ogden Vogt (Art and Religion, 1921), he emphasized the relationship between the arts and religion: 'Art needs religion to universalize its perceptions and relate its concepts.' In return, 'Religion needs the arts to be impressive, to be enjoyable, to vivify its ancient faiths, to kindle new outlooks and to quicken resolves. ${ }^{93}$ The pitfall is to try and reproduce the architecture of another era as if it could respond to the particular needs of a new period. In his view, that is what the Gothic revival was doing and he was advocating against it. ${ }^{64}$ Although he acknowledged that the miracle that happened in the thirteenth century was inspiring and could be re-enacted (given what he analysed as an analogous situation between the birth period of Gothic architecture and his contemporary time), it was not to be imitated in the twentieth century. What was at stake, according to Taylor, was what the Anglican priest and liturgist Percy Dearmer (1867-1936) had identified thirty years earlier: 'the problem of our time is no longer the reconciliation of religion with science, but the reconciliation of religion with art'. ${ }^{65}$

\footnotetext{
${ }^{61}$ Taylor, 'The Spiritual Function of the Church Building. Theme address of the annual meeting of the Church Annual Guild of America at Atlanta, Georgia in March, 1956', RG251, box 2, f. 24, p. 2.

${ }^{62}$ Taylor, 'The Relation of Architecture to the Worship,' p. 3.

${ }^{63}$ Taylor, 'The Relation of Architecture to the Worship,' p. 3. Von Ogden Vogt (1879-1964), Unitarian minister, mostly known for his theory of worship. See http://www.harvardsquarelibrary.org/biographies/ von-ogden-vogt-2/

${ }^{64}$ One of his contemporaries in the USA, the Episcopal priest, seminary professor and dean, and liturgical scholar William Palmer Ladd (1870-1941), fiercely criticized the architectural heritage (or lack thereof) of the Oxford Movement: 'Instead of building on the fine liturgical tradition of the non-jurors, which had been so successfully popularized by John Wesley, its leaders turned with longing eyes toward Rome. To a serious degree they were mere copyists and sentimentalists[.] We see them roving about England, desecrating its cathedrals and parish churches, spending vast sums on "restoration" and replacing the old by their childish make-believe Gothic.' William Palmer Ladd, Prayer Book Interleaves, Appendix, 'The History of the Liturgical Movement', p. 166. Ladd called the new Gothic churches in the USA 'St. Obsoletus', being a 'mistake from the beginning', Prayer Book Interleaves, Miscellany, 'Ex Occidente Lux', p. 128.

${ }^{65}$ Taylor, 'The Relation of Architecture to the Worship', p. 3. See P. Dearmer, Art and Religion (London: Student Christian Movement, 1924), pp. 31-32.
} 
If this was perhaps more obvious for Taylor in the USA, his work in China had meant to deal with this problem as well: his art (architecture) made him particularly sensitive to the place and context in which (Chinese) people were to worship. Art reconciled with religion meant an art in which 'the transcendent meaning of reality [would] shin[e] through completely realistic and concrete forms ${ }^{\prime}{ }^{66}$ As such, architecture was a language and, as a language, needed to be understandable for people to whom it was addressed. Christian architecture was to be understandable for Christians. More specifically, Christian architecture in the West had to be understood by Westerners, and that particular language had to be translated into a Chinese Christian architecture. The pitfall was to try and translate Western Christian architecture into Chinese Christian architecture. The real translation at stake was from Christian architecture into Chinese Christian architecture. Yet, that translation was done by Westerners whose conception of Christian architecture was influenced primarily by Western Christian architecture. Moreover, as we have seen in Taylor's case, the very selection of what constituted 'Chinese' features to be incorporated into the Chinese-Christian buildings was problematic, if done by a Westerner. What Taylor chose was primarily what he could see as typically Chinese through his Western lens. However, Taylor consistently challenged the idea that Western Christian architecture (especially the Gothic style) was (if not the only and true way) the best way of expressing the transcendent. Not every people, every culture, would apprehend the transcendent through the same forms.

So, what did Taylor consider as good twentieth-century American church architecture? It is in his address of 1956 that he gave a few examples of successful constructions. St Thomas's on Fifth Avenue in New York (built by the firm of Cram, Goodhue and Ferguson), or St Bartholomew's on Park Avenue (built by Bertram Goodhue) were, among a few others, exceptions (something surprising, at least concerning St Thomas's, given Taylor's opinion on the new Gothic). But, in general, he said: 'we have failed in both the so-called traditional or eclectic and in the contemporary or non-traditional. ${ }^{67}$

Drawing on Dearmer's observation, Taylor argued that this was due to a divorce between art and people: architects were not focusing on architecture as a religious expression. Instead, they were doing 'architecture qua architecture'. ${ }^{68}$ And (Protestant) clergy were also responsible for this discrepancy. He agreed with Tillich's statement that Protestantism seemed to have lost or to be losing the sense of the sacramental, and that disconnection was visible, according to Taylor, in contemporary church architecture. If innovations taken by the clergy were not liturgically or scripturally sound, that would become visible in the new buildings. In short, Taylor considered that architecture, influenced by and mirroring the culture in

\footnotetext{
${ }^{66}$ The Spiritual Function of the Church Building', p. 4. Taylor is adapting thoughts from Tillich about language.

${ }^{67}$ The Spiritual Function of the Church Building', p. 2.

${ }^{68}$ 'The Spiritual Function of the Church Building', p. 3. One could think here of Taylor's earlier comments on the importance, for missionaries, to get to know the Chinese people. See letter of 7 June 1925, RG251, box 1, f. 5, p. 2. To favour Western architecture in China would also have been, at least partly, to favour architecture qua architecture over the relationship between art and people. Taylor wanted to design buildings that would fit in the Chinese landscape but also use symbols that would speak to Chinese people, so they could make the building their own.
} 
which it had emerged, was reflecting back to the clergy a disconnection between practices, meaning and purpose. What was 'the raison d'être' of the Church and 'the church's relation to society'? 99

Two crucial elements were at stake for Taylor: liturgy and sacrament. After defining liturgy as the collective act of the people and sacrament as a 'spiritual sign, seal, or bond; a covenant, especially one between God and man', he suggested that the building of a church is a 'liturgical act resulting in a physical structure which has sacramental character. ${ }^{70}$ An architecture focusing on styles was analogous, in his view, to the worship of false gods.

Perhaps we see in these later considerations a fundamental element that was missing in his early years as an architect in China. By selecting seventeenth- and eighteenth-century monumental architecture, did not Taylor divorce the actual Chinese people with whom he was working from their contemporary architecture? Though what he ended up imitating from the much-elaborated monuments were some designs - while he imitated roofs for the climate - we do not have evidence of his interest in encountering Chinese architects per se.

As an art intrinsically marked by its purpose - that is, bearing in mind the use people would have of it - architecture could not be sensibly conceived apart from its context, surroundings and meaning. ${ }^{71}$ Taylor was aware of it but it seems that, as a man of his own time, he still believed that he, a Westerner, could do it for the Chinese. That the Christian buildings he created were more 'Chinese' perhaps reflected, in this art form which is both a sign and witness of a people's relationship to power, the transfer of power that was taking place while he was there. To find inspiration in the imperial monuments in the early years of the Chinese Republic, to create Christian buildings in China when one is an American of English ancestry at a time China fiercely rejects colonialism, foreign power and Christianity, must have placed Taylor in quite an odd situation. But back in the USA, he was confronted with another form of difficult translation: from the Gothic Christian art to something yet unknown.

\section{Conclusion}

We are as old as England and even Rome, in law and government, as old as any of Europe, even Rome and Greece in architecture, engineering, art and literature. In science we trace our inheritance to Egypt and Asia, as in religion. If I thought that I represented a civilization and culture which is only three

\footnotetext{
${ }^{69}$ The Spiritual Function of the Church Building', p. 3.

${ }^{70}$ 'The Spiritual Function of the Church Building', p. 3.

${ }^{71}$ Both in China and in the USA, the question of 'blended in' buildings was at stake, though more obviously challenging in China for Western architects tempted to reproduce the architecture of their home countries, and believing that religious symbolism had been captured once and for all in the Gothic style. If the challenge in China was to imagine designs that would both incorporate indigenous architecture (foreign to the architects) and Christian symbols (familiar to the architects), the challenge in the USA was to try and go beyond the Gothic style. Religious symbols did not have to be 'translated' but incorporated into another style yet to be imagined.
} 
hundred years old, I could not presume to come as a missionary and teacher to this ancient nation. ${ }^{72}$

This is how Taylor considered himself as an American in China. As we have seen in numerous examples, he tried to put things into perspective, considering the heritage of his own country and of the country where he was serving as a missionary, in order to reflect more accurately on the specific needs of his own time. Aware of the architectural transitions in both China and the USA, he was eager and committed to discern what kind of architecture would be best attuned with its particular period. Aesthetics was important insofar as it bore meaning and was meaningful indeed for the people for whom it was supposed to speak. Church architecture seemed therefore key in creating relationships, in embodying (making physical) the relational aspect of religion: it was a medium for the relationship of people with each other (its liturgical aspect) but also for the relationship of people with God (its sacramental aspect).

However, reservations may be expressed as to whether he practised in China what he communicated years later. One can be perplexed by the reasoning that led Taylor to mock those who saw in Gothic style the essence of Christian architecture and dismiss the (new) Gothic as 'a high degree of absurdity resulting from backward looking romanticism', though it did not impede him from looking into the Qing dynasty as the essence of Chinese architecture. ${ }^{73}$ His selection of seventeenth- and eighteenth-century monumental Chinese buildings presented as typically Chinese, as 'the' Chinese style, may underline that Taylor was not so much in touch with the indigenous people, their contemporary architecture, or their political context - as it is also reflected in his colonialist and racist remarks. Rather, his eyes selected a style and historical period that his remote and foreign knowledge of Chinese architecture had identified as archetypal, through the exotic lens of colonialism.

For one thing, Taylor's stay in China was rather brief, which may have limited his exposure to native Chinese architecture. Needless to say that the riots and the fact that certain sites were not easily accessible must have impeded him from exploring more of Chinese architectural styles over centuries and across a wide land. ${ }^{74}$ To choose 300-year-old buildings erected for imperial power while China was becoming a republic, and which are only indirectly connected to places of worship, may seem counter-intuitive. In short, he tried to learn Chinese, while still thinking in his native language. Yet, because he learned about aspects of Chinese architecture and imitated parts of it, while incorporating Christian symbols into it, Taylor participated in architectural accommodation. If these buildings were still showing the stamp of foreign power, they may also have been registering a shift.

\footnotetext{
${ }^{72}$ Letter to his family, 28 December 1925, RG251, box. 1, f. 5, p. 6.

${ }^{73}$ 'The Relation of Architecture to Worship', p. 2. One can draw a parallel between his essentialist approach and the romantic nationalism emerging in the late nineteenth century. See Rosalind Polly Blakesley, The Arts and Crafts Movement (New York: Phaidon Press, 2006).

${ }^{74}$ The German architect Boerschmann had encountered similar difficulties when he visited China between 1906 and 1909, some sites being unreachable. See Kögel, The Grand Documentation, p. 72.
} 


\section{Bibliography \\ Archives}

Taylor Papers (Walter and Ruth Marie), 1923-1954, 2 linear feet (3 boxes), RG251

\section{Secondary resources}

Boerschmann, Ernst, Picturesque China. Architecture and Landscape. A Journey Through Twelve Provinces (trans. Louis Hamilton; London: Adelphi Terrace, [n.d., acquired by the Bodleian Library in June 1924])

Cram, Ralph Adams, Impressions of Japanese Architecture and The Allied Arts (New York: The Baker \& Taylor Company, 1905)

Cram, Ralph Adams, My Life in Architecture (Boston: Little Brown, and Company, 1936)

Cram, Ralph Adams, The Sins of The Fathers (Boston: Marshall Jones Company, 1919)

Ladd, William Palmer, Prayer Book Interleaves. Some Reflections on How the Book of Common Prayer Might Be Made More Influential in our English-Speaking World (Oxford: Oxford University Press, 1942, Reprint, New Edition in conjunction with Berkeley Divinity School at Yale, 2018)

Taylor, Walter A., 'The Architect Looks at Research', Journal of Architectural Education, 1.1 (1947), pp. 1324 (Online: Routledge)

Taylor, Walter A., 'A School of Architecture of the Future', Journal of Architectural Education 14.2 (194774), ACSA-AIA Seminar: The Teaching of Architecture (Autumn, 1959), pp. 48-52 (Online: Taylor and Francis)

Taylor, Walter A., 'The Continuing Educational Process', Journal of Architectural Education, 4.1 (1949), pp. 47-51 (Online: Routledge)

\section{Books Taylor was reading while in China}

Ellis, Havelock, The Dance of Life (Boston: Houghton Mifflin Company, 1923)

Fosdick, Harry Emerson, Twelve Tests of Character (New York: George H. Doran Company, 1923)

Sedgwick, Anne Douglas, The Little French Girl (Boston and New York: Houghton Mifflin Company, 1924)

\section{Secondary resources}

Blakesley, Rosalind Polly, The Arts and Crafts Movement (New York: Phaidon Press, 2006)

Bremner, G.A., Imperial Gothic: Religious Architecture and High Anglican Culture in the British Empire, $c$. 1840-1870. (New Haven, CT: Yale University Press, 2013)

Cai, Yanxin, Chinese Architecture (trans. Andrea Lee, Selina Lim, David Gu; Cambridge: Cambridge University Press, 2011)

Chambon, Michel, 'The Action of Christian Buildings in their Chinese Environment', Studies in World Christianity (Edinburgh: Edinburgh University Press, 2017), 23(2), pp. 100-121

Chow, Alexander, 'Editorial: Chinese Identity, Christian Identity', Studies in World Christianity (Edinburgh: Edinburgh University Press, 2017), 23(2), pp. 97-99.

Coomans, Thomas, 'A Pragmatic Approach to Church Construction in Northern China at the Time of Christian Inculturation: The Handbook "Le Missionnaire constructeur", 1926', Frontiers of Architectural Research 3 (2014), pp. 89-107

Esherick, Joseph W., The Origins of the Boxer Uprising (Berkeley, CA: University of California Press, 1988)

Fu Xinian, Guo Daiheng, Liu Kujie, Pan Guxi, Qiao Yun, Sun Dazhang, Chinese Architecture (New Haven, CT: Yale University Press; Beijing: New World Press, 2002), English text edited and expanded by Nancy S. Steinhardt

Fry, Roger, 'Chinese Art and Architecture', in China, Body and Soul (contributions by Laurence Binyon, Roger Fry, E.R. Hughes [and others]; ed. E.R. Hughes; London: Secker and Warburg, 1938), pp. 27-43.

Hall, Michael, George Frederick Bodley and the Later Gothic Revival in Britain and America (New Haven, CT: Yale University Press, 2014)

Ho, Puay-Peng, 'Mind the Gap: Bridging Historiography on Chinese Architecture in the Early Twentieth Century', Art in Translation, 5.2 (2013), pp. 297-311 (Online: Routledge) 
Hollinger, David A., Protestants Abroad: How Missionaries Tried to Change the World but Changed America (Princeton, NJ: Princeton University Press, 2017)

Hung, Wu, Monumentality in Early Chinese Art and Architecture (Stanford, CA: Stanford University Press, 1995)

Kögel, Eduard. The Grand Documentation: Ernst Boerschmann and Chinese Religious Architecture (19061909) (Berlin: De Gruyter, 2015)

Liu, Laurence G., Chinese Architecture (London: Academy Editions, 1989)

Liu, Jin, 'Component-Driven Procedural Modeling for Ancient Chinese Architecture of the Qing Dynasty', International Journal of Architectural Heritage, 12.2 (2018), pp. 280-307 (Online: Taylor \& Francis)

Po-Hsia, R., A Jesuit in the Forbidden City: Matteo Ricci, 1552-1610 (Oxford: Oxford University Press, 2010)

Rajagopalan, Mrinalini and Desai, Madhuri, Colonial Frames, Nationalist Histories: Imperial Legacies, Architecture, and Modernity (Farnham, Burlington: Ashgate, 2012)

Starr, Chloë F., Chinese Theology: Text and Context (New Haven, CT: Yale University Press, 2016)

Wickeri, Philip L., 'Anglicanism in China and East Asia, 1819-1912', The Oxford History of Anglicanism, (Oxford: Oxford University Press, 2017), III, ch. 15, pp. 318-37

Wickeri, Philip L., 'The Vicissitudes of Anglicanism in China, 1912-Present', The Oxford History of Anglicanism (Oxford, New York: Oxford University Press, 2018), V, pp. 148-68

Zhao, Xiaoyang, 'Rejuvenation after Encounters between Different Artistic Forms: A Synopsis of Studies of Indigenization of Christian Art in China', Journal of Modern Chinese History 8.2 (2014), pp. 258-71 (Online: Routledge)

Cite this article: Burette, S. (2022). Learning Chinese: Walter A. Taylor, an American Architect in China (1923-27). Journal of Anglican Studies 20, 40-66. https://doi.org/10.1017/S1740355321000061 